Portela, E.C.; Becker. E.L.S.; Santos, R.P.; Pereira, J.C.K. Ecoturismo e Educação Ambiental: uma proposta para a recuperação e proteção do patrimônio histórico e natural da barragem do Rio Vacacaí Mirim, Santa Maria (RS). Anais do VIII Congresso Nacional de Ecoturismo e do IV Encontro Interdisciplinar de Ecoturismo em Unidades de Conservação. Revista Brasileira de Ecoturismo, São Paulo, v.4, n.4, 2011, p. 537.

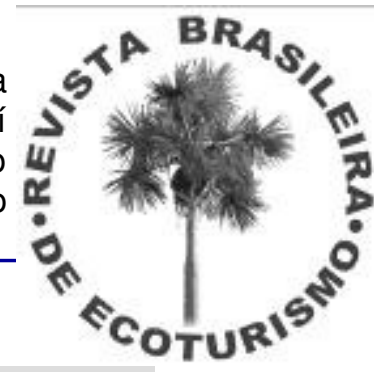

\title{
ECOTURISMO E EDUCAÇÃO AMBIENTAL: UMA PROPOSTA PARA A RECUPERAÇÃO E PROTEÇÃO DO PATRIMỐNIO HISTÓRICO E NATURAL DA BARRAGEM DO RIO VACACAÍ MIRIM, SANTA MARIA (RS)
}

\author{
Eliane Carine Portela*, Elsbeth Léia Spode Becker**, \\ Roselena Pereira dos Santos ${ }^{\star * *}$, Joelmir Christian Kuntz Pereira ${ }^{\star * * *}$ \\ *Turismóloga-Agente de viagens, **UNIFRA, ${ }^{* * * T u r i s m o l o g a, ~ * * * * T u r i s m o ́ l o g o ~}$ \\ E-mails: elianeventur@hotmail.com, elsbeth.geo@gmail.com, fofapr@hotmail.com, \\ chris-turismo@hotmail.com
}

Este trabalho tem como principal objetivo propor a recuperação e proteção do patrimônio histórico e natural no entorno da Barragem do Rio Vacacaí Mirim, na cidade de Santa Maria, Rio Grande do Sul. A barragem tem grande relevância por ser responsável em abastecer cerca de $40 \%$ da população da cidade. Sua construção, na década de 1980, decorreu das estiagens prolongadas nos meses de verão e também, do aumento da população em função da cidade tornar-se aporte de um crescente número de estudantes do ensino superior e de militares do exército e da aeronáutica. A construção do reservatório, no entanto, motivou a extinção do famoso Parque da Montanha Russa, que submergiu sob as águas da represa. O Parque da Montanha Russa era um importante atrativo turístico e de lazer para os habitantes de Santa Maria e da região. No período de 1907 e 1932, foi considerada, uma área nobre da cidade e ponto de encontro da sociedade Santa-mariense. Nas décadas posteriores, com a construção de clubes na cidade, o local sofreu um gradual desinteresse da população e descaso da administração municipal. Muitos habitantes de Santa Maria sequer lembram que, sob as águas da Barragem que abastece a cidade, existiu um grande atrativo turístico, que movimentava o fluxo de pessoas e trazia visitantes de outras localidades. Assim por meio desta proposta e da prática do ecoturismo voltado para educação ambiental e preservação do ambiente, pretende-se: despertar a consciência ambiental do visitante e do morador, além de resgatar a história de um passado glorioso e um novo cenário no entorno da Barragem. Para o desenvolvimento desta pesquisa, foram consultadas obras que abordam os seguintes temas: ecoturismo; sustentabilidade ambiental; educação ambiental; sustentabilidade sociocultural e resgate da memória local. A metodologia utilizada foi a pesquisa qualitativa de caráter exploratório e descritivo, com base nas pesquisas bibliográficas e nas entrevistas semiestruturadas com moradores do entorno da Barragem. Constatou-se que o ambiente no entorno da Barragem encontra-se degradado e a maioria dos moradores habita em condições mínimas de saneamento básico. Além disso, o local é reconhecido como uma área para a prática de vandalismos como saques, pequenos assaltos e outros delitos. Diante desta realidade, percebese a necessidade de projetos que promovam a conservação e valorização do entorno do reservatório, bem como resgate do passado histórico-social. Acredita-se, desta maneira na possibilidade de desenvolver o ecoturismo aliado a educação ambiental, através de roteiro turístico guiado, tendo como base alguns dos pontos citados nas entrevistas com os moradores. Cabendo ao final do passeio a cada um, individualmente ou em grupo, o entendimento que todos são responsáveis pela construção do espaço público voltado as práticas turísticas onde a cidadania e a democracia deve estar presentes. Da coletividade e da solidariedade, será possível pensar em um futuro melhor, num mundo sustentável e em uma nova ética pautada no respeito ao outro e ao mundo onde se vive.

Palavras-chave: Ecoturismo; Patrimônio ambiental; Patrimônio sociocultural. 